A N N A L E S

UNIVER S T ATIS M A R A E C URIE-SKŁODOW K A

LUBLIN - POLONIA

VOL. LXXIV

SECTIO F

2019

Jan Evangelista Purkyně University in Ústí nad Labem

ANTONÍN KADLEC

ORCID: https://orcid.org/0000-0002-6485-5329

kadlec.antonin@npu.cz

\title{
Falchion - Weapon Which Tells a Story. \\ $A$ Word on the Discussion on the Epitaph of Jan of Jeřeň
}

Miecz - broń, która opowiada.

Głos do dyskusji nad Epitafium Jana z Jeřeně

\section{SUMMARY}

The article extends a contemporary discussion about the Epitaph of Jan of Jeřen and argues that these two male saints who are traditionally referred to as Bartholomew and Thomas do not have to be the only interpretation here. Simultaneously, it shows us the basic need to deal with the concrete objects displayed. These can essentially influence the narrative potential of the artwork. This study points out the desirable multidisciplinary approach that is being demonstrated here by an example of a type of an object (falchion) in relation to a medieval art of Central Europe.

Keywords: history; culture; art; Wenceslas IV; falchion; Epitaph of Jan of Jeřeň; St. Paul; Middle Ages

\section{INTRODUCTION}

The history of material objects, in particular of weapons in the second half of the $20^{\text {th }}$ century, became a carefully observed path of learning history. Interest in this subject matter was undoubtedly raised by new visual media in which - even to present political history playing the major role in the arena of history throughout many centuries - the visualisation of these objects is necessary.

In the Czech context, the interest in this topic - directly related to filmography - can be observed both amongst specialists and amateurs at least from the 
times of the publication by Eduard Wagner. ${ }^{1}$. This work, outdated to a large extent, is still an inseparable volume in the bibliography of people interested in historical film productions or the so-called reenactments. However, tradition of expressing interest in "the history of objects" goes back even further to the past; one is reminded here about the works of, e.g. Čeněk Zíbrt ${ }^{2}$, while this subject matter can be found abroad much earlier, e.g. in the works by Eugène Violett-le-Duc, August Demmin or Wendelin Boeheim ${ }^{3}$. Academic and amateur interest was obviously expanding in the second half of the $20^{\text {th }}$ century. The most important experts in the military scope of the history of object are, therefore, people such as Jan Durdík, Petr Klučina, Ctirad Beneš, Leonid Křížek, and some others could also be listed ${ }^{4}$. Josef Petrán̆ made a golden name for himself in the problem matter of the material culture in the Czech context ${ }^{5}$.

Not only a number of scientists but also members of amateurish audience are involved also these days in researching works of art as secondary sources for learning about material objects ${ }^{6}$. The voice in discussion is obviously expressed to some extent also by quite a few art historians because the examined objects often influence the compositional order of the work, and thus they are important for both the art history and for, e.g. the history of thought.

I would like to contribute to this extensive discourse by analysing the presentations of a specific object, the so-called dussack (tesák/tasak/dusack/falchion), and also by offering a theory which places this weapon in the system of figurative objects used in a broader timeframe horizon with a particular emphasis on the turn of the $14^{\text {th }}$ and $15^{\text {th }}$ centuries. On the basis of this hypothesis, I would also like to propose an alternative interpretation of the Epitaph of Jan of Jeřen and, thus, try to effectively link the topic of the articles with both the history of material objects as well as art history. As has been already mentioned, the particular

1 E. Wagner, Z. Drobná, J. Durdík, Kroje, zbroj a zbraně doby predhusitské a husitské, Praha 1956.

2 Č. Zíbrt, Dějiny kroje v zemích českých od dob nejstaršich až po války husitské, Praha 1892.

3 E.E. Viollet-le-Duc, Dictionnaire raisonné du mobilier francais V, Paris 1874; A. Demmin, Encyklopädie der Waffenkunde, Leipzig 1893; W. Boeheim, Handbuch der Waffenkunde, Leipzig 1890.

4 On the discussion on this matter, see publications by, e.g. E. Wagner, Z. Drobná, J. Durdík, op. cit.; J. Durdík, Husitské vojenství, Praha 1953; P. Klučina, A. Romaňák, Člověk, zbran̆ a zbroj v obraze doby 5.-17. stol., Praha 1983; P. Klučina, Zbroj a zbraně. Evropa 6.-17. století, Praha-Litomyšl 2004; C. Beneš, O. Gamber, Ochrané zbraně: České vydání, Graz 1972; L. Kř́žek, J.K.Z. Čech, Encyklopedie zbrani a zbroje, Praha 1997.

5 J. Petráň, Dějiny hmotné kultury I, Praha 1985.

6 Selectively, e.g. P. Voda a kol., Předběžná zpráva o oděvní analýze nástěnných maleb v kostele ve Slavětíně nad Ohř́, [in:] Sborník semináře historie odivání. Díl druhý, Zlín 2009, pp. 5-10; I. Dubec, Válečné a turnajské erbovní odění v 1. polovině 14. století, [in:] Sborník semináre historie odivání, Zlín 2009, pp. 81-104.

7 A word falchion could be most evidently used but I will follow the tradition in academic works, to which Petr Klučina, who recognises falchion as a type of a dussack, remains faithful. See, e.g. P. Klučina, op. cit., p. 238. 
element on which the attention will be focused is the weapon that can be referred to as a falchion.

\section{$\operatorname{DUSSACK}(?)$}

Dussack as a weapon has already been studied in the past by many of the above-mentioned authors. The most detailed work on the dussack is currently a dissertation thesis by Petr Žákovský8. However, there has been so far no attempts to make a more comprehensive interpretation of the meaning of this object in the artistic works 9 . First of all, it is necessary to define what could and what could not be considered as dussack ${ }^{10}$.

At first, a few words on the term. In the Czech provenience, it appears for the first time in 1405 and is associated at that time with a Latin term referring in other contexts to a dagger or a knife - combined culltelus dictus tesák $k^{11}$. It is true that some of the examples of this weapon are indeed similar to a knife and perhaps, in their original form, were inspired by this utilitarian item. At least the single-edged blade and a simple grip without a pommel and a knob correspond to the idea of a knife. Later, however, falchion lost its "knife-like" nature and, in some of its aspects, it started to resemble a sword. Generally speaking, it is possible to agree with a statement that from the half of the $13^{\text {th }}$ century, dussack very often started to appear with a pommels and cross-guards typical for swords. On the other hand, many dussacks from the Middle Ages additionally have extra knuckle guards.

Other terms associated with dussack are words like: falchion, falcione, fauchart,fauchon, Malchus, tesák, Düsack, lang Messer, sekáćc ${ }^{12}$, szabla and others ${ }^{13}$.

8 P. Žákovský, Tesáky a problematika jednosečných zbrani středověku a raného novověku, Brno 2014 (disertační práce, Masarykova univerzita, Filosofická fakulta).

9 Short outline of this subject matter can be found in the Master's thesis, the elaboration of which is presented in this article: A. Kadlec, Zbraně a zbroj v deskové malbě doby vlády Václava IV., Ústí nad Labem 2013 (diplomová práce, Univerzita Jana Evangelisty Purkyně, Filosofická fakulta), pp. 49-53.

10 This is a short introduction to the problem, see more details in: P. Žákovský, Tesáky a problematika...

11 E. Wagner, Z. Drobná, J. Durdík, op. cit., p. 70. Tesák is a Czech version of the Polish word tasak (dussack in English; translator's note).

12 The word sekáč literally means chopper knife in Polish, but this term is not present in the Polish terminology on the melee weaponry. However, it seems that it is a close synonym of the term tasak - and this is how it will be used by the author in the following part of the article. I decided to leave it here in an untranslated form and in the following part of the text I replaced it with the term tasak (dussack or falchion in English; translator's note).

13 E. Wagner, Z. Drobná, J. Durdík, op. cit., p. 71; P. Klučina, op. cit., p. 238, 406, 407; F. Funcken, L. Funcken, Historische Waffen und Rüstungen. Ritter und Landsknechte vom 8. bis 16 Jahrhundert, München 2008, p. 212; A. Demmin, op. cit., p. 396; W. Boeheim, op. cit., p. 271; J. Šach, Chladné zbraně, Praha 2004, p. 34; P. Žákovský, Tesáky a problematika ...; E. Wágner, Seč- 
It should be noted that the vast majority of these words appear much later than a similar weapon in the depicted database of secondary and primary sources. Dussack is also very often referred to with a term covering all long weapons with a hilt - a sword. Additionally, the term dussack is often associated by many authors with other terms, while its general description is very simple. Dussack is a single-edged, short sword-like melee weapon ${ }^{14}$. Due to the fact that there are also dussacks for being used with both hands, classification as a short melee weapon should be treated with reservations.

The word falchion is known from the English-speaking world and has its equivalents in other countries of Western Europe. In the Czech Republic, it is often associated with a single-edged sword, the blade of which broadens towards the point. So it is considered to be a specific type of dussack. Nevertheless, the foreign works often associate it with the Czech word tesák (compare to dussack), without taking into consideration the shape of the blade ${ }^{15}$. Overall, this term can be linked with at least three types of blades of these unique weapons which existed until the beginning of the $15^{\text {th }}$ century ${ }^{16}$.

The first type of blade is bulky and it broadens towards the point, which is situated on the edged side, and then it narrows semi-circularly at the end of the blade like a knife, just as in the case of the falchion of Hamburg ${ }^{17}$ or Durham ${ }^{18}$. In the case of the second type, represented by, e.g. the falchion from Paris, the narrowing is very distinct, concaved, and - because of this - the point on the edged side is very sharp. The last type of the blade has the point situated on the blade. The so-called short blade is created on the edged-side and due to a small bending the weapon resembles a sabre ${ }^{19}$.

Frequent linking of dussack and sabre is worth presenting on the example of a sabre of Arabic origins, dated to 1323 on the basis of inscription to which Demmin draws attention ${ }^{20}$. Some of the falchions from the Wenceslas Bible also resemble sabres. It is also worth mentioning the two-handed sabre from the equip-

né a bodné zbraně, České Budějovice 1993, p. 31. Wágner thinks of a dussack even as a type of an executioner's axe with which Zavis of Falkenstein was supposed to be beheaded. In reality, dussack appears very often not only in the hands of executioners, but also very respected and virtuous biblical characters who do not represent negative features attributed to Zavis.

14 E. Wágner, op. cit., p. 24.

15 See more: P. Žákovský, Tesáky a problematika..., p. 31.

16 A supporter of another classification, although undoubtedly also available for use, is Žákovský (Tesáky a problematika ..., pp. 54-95). For the purpose of this publication its simplified version is sufficient.

17 Dussack from Hamburg, Hamburg, $13^{\text {th }}$ c., Museum für Hamburgische Geschichte, Inv. no. AB.II.176.

18 Conyers falchion, c. 1260-1270, Durham, Treasury of Durham Cathedral.

19 Thorpe falchion, late $14^{\text {th }} \mathrm{c}$., Norwich, Norwich Castle Museum.

20 A. Demmin, op. cit., p. 377. 
ment of Gjergj Kastrioti, known as Skanderbeg, which has almost an identical shape as the two-handed dussacks from the same manuscript and which can be referred to as a sabre ${ }^{21}$. These long weapons, similarly to the bulky dussacks, often referred to as falchions, from the foreign finds revitalise in a sense the definition of the dussack as a short melee weapon. Unusually "pretty" term relating to these curved weapons is a German word säbelföremige Schwert used by Demmin ${ }^{22}$ or an apt term by Boeheim - Krummschwert ${ }^{23}$.

It is also worth to turn the attention to the so-called Czech dussack, an ordinarily built weapon popular in the $16^{\text {th }}$ century, which Meyers (1570) associates - erroneously, according to Demmin - with the term düssack ${ }^{24}$. In the later times, some of the dussacks are transformed into popular hunting weapons and, in their shorter form similar to a knife, they successfully - unlike a sword - play a role of a military weapon, accompanying sabres.

The very Czech term tesák (dussack) reveals for what this weapon was used $^{25}$. First and foremost, it was - at least at the beginning - a cutting tool for combat which is evidenced by the already mentioned bulky falchions from, inter alia, Durham, Hamburg and Poznań. Falchion, similarly to sword, developed as a response to the increasingly more excellent protective equipment, which gradually prevented a warrior's body from a threat of being cut. Therefore, falchions with a sharp point - which could penetrate between sheets or tear a chain armour easier than the weapons of a relatively blunt point similar to the sword of St. Peter of Poznann ${ }^{26}$ - started to appear. This is the way through which I associate the transformation of weapons directly with the development of a high quality of protective equipment. The change in the construction of the blade was at the same time minimal ${ }^{27}$. Therefore, the bulky falchions from the so-called Crusader Bible, also known as Maciejowski Bible, are unique. Their sizes correspond with other types of falchions but the weapon is already taking on an exotic look, in this case enhanced by the complexity of the cutting blade, enriched with various kinds of hooks and edgings ${ }^{28}$. But are they real?

21 E. Wagner, Z. Drobná, J. Durdík, op. cit., p. 71.

22 A. Demmin, op. cit., p. 396. Loosely translated as: "a sword similar to a sabre".

23 W. Boeheim, op. cit., p. 271. Loosely translated as: "a curved sword".

24 A. Demmin, op. cit., p. 370.

25 Language analysis of this term in the work by T. Ptáčková, Pưvod názvi̊ středověkých zbrani použivaných v Čechách a na Moravě (zbraně chladné - sečné a bodné), Brno 2010, p. 51. The Czech word tesák (transferred to dussack) is associated with the verb tesat which in Polish means ciosać, obciosywać ("to hew" in English; translator's note).

26 Sword of St. Peter, Muzeum Archidiecezjalne in Poznań.

27 See attachment no. 2.

28 P. Klučina, op. cit., p. 242. For example, Viollet-le-Duc gives the name fauchon or fauchard also to the long, cutting and stabbing weapon in different variations with a blade similar to a falchion (E.E. Viollet-le-Duc, op. cit., p. 490). 
In order to notice the details and interpret them, it is worth referring to all these types of weapons as dussacks (although there are many opponents to this approach) just as it was done by the eldest historians ${ }^{29}$, and thus concentrate on searching for a single-edged weapons equipped with a hilt. To tag these items as machetes, falchions, or long knives, etc. is therefore a purely subjective matter, which - in my opinion - has no truly solid historical justification but somehow, we have to work with them.

\section{FALCHION IN ART}

There is a relatively high number of representation of this weapon from the turn of the $14^{\text {th }}$ and $15^{\text {th }}$ centuries. We also have at our disposal an extensive collection of material objects which - with a varying accuracy - can be ascribed to this broad timeframe. However, at least on a Czech front, these two sets of information have no common elements. In other words - dussacks from the turn of the $14^{\text {th }}$ and $15^{\text {th }}$ centuries do not resemble their counterparts in art.

At first, it is worth drawing attention to the fact that dussacks appear in many different branches of visual art: panel and wall paintings, and manuscript illuminations, as well as in carved works. The analysed object was used in the panel paintings in the following works: Resurrection by the Master of the Třeboň Altarpiece, Epitaph of Jan of Jeřen̆, and Martyrdom of a Saint ${ }^{30}$, and if one is to consider falchion as a weapon similar to a knife behind the belt of one of the soldiers, then also in the Crucifixion of Saint Barbara. The falchion is present in the illuminations in a few manuscripts of Czech origin. The most depictions of this weapon is in the Wenceslas Bible, they also appear (although less often) in other manuscripts, e.g. the Bible of Conrad of Vechta, the Bible of Litomerrice and Třebor̆, and the Bible of Bozkov. In the wall paintings, on the other hand, falchion is a weapon of the executioner of St. Dorothy from the church in Rakovník. Moreover, it can be spotted on the paintings in the Church of St. Jacob in Bedřichův Světec, the Church of St. Stephen in Kouřim, or the Church of St. Margaret in Loukov. In all cases, the weapon is used for carrying out executions. In order to see falchion in sculpture, it is necessary to visit, e.g. the Bavarian Nuremberg where it is held by Saint Catherine in a relief of three saints in the Church of Saint Lawrence.

29 I adhere to the tradition of works by Klučina who refers to the discussed weapons as falchions. See, e.g. P. Klučina, op. cit., p. 239.

30 The painting Martyrdom of a Saint does not come directly from the territory of Bohemia but its author was probably closely linked to the Czech artists. See Karel IV. Císař z Boži milosti. Kultura a uméní za vlády Lucemburků 1310-1437, ed. J. Fajt, Praha 2006, p. 194. 
With an exception of the above-mentioned weapon, which is nevertheless commonly referred to as a knife and not a falchion ${ }^{31}$, the majority has a form of exotically-looking curved sword (falchion) with a point in the line of a long blade overlapped by a short blade which turns into an unsharpened part of the blade, that is - a ridge. Apart from the falchion presented in the Bible of Litomerrice and Trebon̆, all the others have a pommel and a cross-guard just like swords. They visibly broaden from the knob towards the beginning of a short blade, and therefore their form is a combination of the bulky falchions from the middle of the $13^{\text {th }}$ century and rather "delicate" weapon from the museum in Norwich. Other exceptions are two-handed, curved swords referred to as cleavers or sabres ${ }^{32}$ in the Wenceslas Bible, which lack a short blade and which start narrowing towards the point already from the cross-guard ${ }^{33}$. Therefore, their shape, as has been already mentioned, is nearly identical with the shape of a curved sword of the Albanian hero, Skanderbeg ${ }^{34}$.

It is often very difficult to date archaeological finds and as a consequence the traditional falchions considered to be from the beginnings of the $15^{\text {th }}$ century are - in accordance with the new research - placed in later periods ${ }^{35}$. However, this does not change the fact that the counterparts of falchions from varied types of artistic creativity has by no means survived in the Czech archaeological material from the period under discussion, and the falchions in question have a different shape. The latter are primarily simple examples, similar to a knife, with the point in the central ridge of the weapon ${ }^{36}$.

Such a discrepancy between the artistic material and the finds is not too frequent in the case of earlier periods. At the turn of the $14^{\text {th }}$ and $15^{\text {th }}$ centuries, art was still a medium for dissipating information - e.g. Saint Wenceslaus was clad in a type of armour which was widespread in the moment of making the artwork and not from the times when the saint was actually alive; on the other hand, his equipment was supplemented with conventional elements which were directly indicating his person, the so-called attributes. The duke's hat did not reflect any longer the reality of the old days, but their experience. The objects performing this narra-

31 Cf. E. Wagner, Z. Drobná, J. Durdík, op. cit., část obrazová V, tab. 3, sine pag.; P. Žákovský, Tesák z holešické tvrze na př́bramsku, [in:] Non sensistis gladios. Studia ofiarowane Marianowi Gloskowi w 70. rocznicę urodzin, red. O. Ławrynowicz, J. Maik, P.A. Nowakowski, Łódź 2011, p. 530.

32 E. Wagner, Z. Drobná, J. Durdík, op. cit., část obrazová V, tab. 13, sine pag.

33 Bible Václava IV., Cod. 2759-2764, Österreichische Nationalbibliothek, Wien, vol. I, 176, illustration: The Israelites were defeated.

34 W. Boeheim, op. cit., p. 272.

35 See, e.g. P. Žákovský, Tesáky ze sbírek Státního hradu Zvíkova, „Castellologica Bohemika“ 2008, roč. 11, č. 1, pp. 461-472.

36 On this topic see, e.g. Ibidem, pp. 461-472; idem, Tesáky s prořezávanými záśtitnými trny z moravských sbirek, „Archeologické rozhledy“ 2011, roč. 62, č. 3, pp. 501-516. 
tive function are generally referred to as figures. However, they can take different forms, similar to real or fantasy objects ${ }^{37}$. Undoubtedly, the painters often used templates so the representations are not necessarily a reflection of the author's experience with the real object, although one should search for some element of reality in the objects which were products of imagination.

Some falchions are most certainly presented as figures. The falchion as an attribute can be seen in the hands of Saint Catherine ${ }^{38}$, Saint Judith ${ }^{39}$ or characters from the Epitaph of Jan of Jeřeñ ${ }^{40}$. As will be explained below, also the falchions of executioners from the Martyrdom of a Saint or scenes from the Execution of St. Dorothy of Rakovník can be regarded as figurative objects and, moreover, directly associated with the presented scene. Falchions appear also in the scenes in which they do not play an identifying role (Massacre of the Innocents ${ }^{41}$, Samuel quartering $\mathrm{Agag}^{42}$, War with the Amorites ${ }^{43}$, and many more). The weapon is presented in the hands of both the Old Testament Jews ${ }^{44}$ and their opponents ${ }^{45}$, while in the New Testament it is held primarily by the Romans ${ }^{46}$. In all these cases religious scenes are concerned. However, the curved swords can be seen abroad also in secular works, mainly in the battle scenes between a Christian and a pagan. A motif of an ineffective battle of Béla IV with the Tatars ${ }^{47}$ can serve here as a representative example. Similar impressions can be observed in the scenes from the legend of Saint Ladislaus, but here the saint knight is successful in the fight ${ }^{48}$.

Therefore, what connects all these works is not a specific religion but probably different cultural, chronological, and perhaps also geographical origins of the fighting figures. Difference in cultures is evident most of all in the secular repre-

37 On figures in art, see first and foremost: P. Francastel, Figura a místo. Vizuální řád v italském malírství v 15. století, Praha 1984.

38 Catherine from the relief of the three saints from the Church of St. Lawrence in Nuremberg (the relief of three virgins - Barbara, Catherine, Anna, c. 1410). Another example is St. Catherine from the Altar in Graudenz which was strongly influenced by the Master of the Třebon̆ Altarpiece (J. Royt, Mistr Třeboňského oltáře, Praha 2013, pp. 188-189).

39 Bible boskovská, sign. M III 3, Státní vědecká knihovna Olomouc, Olomouc, card 211v, illustration: Judith beheads Holofernes.

40 Epitaph of Jan of Jeřeň, 1395, NG, Praha, i.č. O 1268.

41 Bible litoměřicko-třeboňská, BIF 3-2, Státní oblastní archiv Litoměřice, Litoměřice, card 19r, illustration: The Slaughter of the Innocents.

42 Bible Václava IV., Cod. 2759-2764, Österreichische Nationalbibliothek, Wien, vol. I, card 50, illustration: Samuel quarters Agag.

43 Ibidem, vol. I, card 177, illustration: Battle with the Amorites.

44 Ibidem, vol. II, card 69, illustration: And David set off and lost the land.

45 Ibidem, vol. I, card 176, illustration: The Israelites were defeated.

46 See, e.g. Mistr Třeboňského oltáře, Zmrtvýchvstání Krista, (1380) NG, Praha, i.č.: O 477a.

47 Chronicon Pictum, Marci de Kalt, chronica de gestis Hungarorum ab origine gentis ad a. 1330, Országos Széchényi Könyvtá, Budapest, Cod. 404, card 63.

48 E.g. in the attic of the church in Necpaly. 
sentations of the duel between a Christian and a pagan warrior. Additionally, one can also often observe in the Biblical scenes, e.g. exotic headgears, which are most certainly a reference to another dimension in which the events had taken place, just like the weapon of an unconventional look that the warriors used ${ }^{49}$. Swords are replaced in these scenes with falchions and this kind of change is also visible in other representations. It is an important indication that these objects were replaced by the falchion in representations where - in other instances - a sword was fully used in accordance with tradition. The sword is without a doubt a conventional attribute of St. Catherine. Why was it replaced with the falchion on a relief from Nuremberg? Both in the hagiography and poetry of that time, Catherine, similarly to St. Dorothy, was supposed to be beheaded only with a sword" ${ }^{50}$ : "Here then, those breasts of the queen / they are miserably ripped from her body, / then they beheaded her / with a sword [...]" "W "When she bowed her head for the sword / at that moment appeared / a very beautiful baby, / dressed in purple, / carrying fruit in a basket, / three apples and three roses / in the month of February $[\ldots]^{\prime 55}$.

Presenting those saints with a sword is thoroughly common in the discussed period. Why then are we dealing with "rearming" the saint in those marginal cases? Is it possible that the replacement of this weapon with a falchion is to indicate once more the pagan environment in which these events took place? In this metaphoric way the work explains to its observer that Christianity has nothing in common with the saint's death, that no one else is guilty of it but a pagan. However, there is also the representation of St. Judith holding a falchion. This saint was not a pagan but it should be remembered that the weapon which caused Holofernes to lose his life was his own weapon ${ }^{53}$.

These events were also supposed to take place on a culturally different territory which - during the creation of the above-mentioned works of art - was pagan and thus the representation of falchions instead of a traditional Central European

49 Bible Václava IV., Cod. 2759-2764, Österreichische Nationalbibliothek, Wien, vol. I, card 31v, illustration: Laban and Jacob.

50 Golden Legend does not define more closely the executioner's weapon in any of the saints (J. de Voragine, Zlatá legenda, Praha 2012).

51 J. Vilikovský, Legenda o svaté Kateřině, Praha 1946, p. 139. The author's own translation. In the old-Czech original: "Tu pak ty královéj prsi / jakž nuzně z těla vydřechu, / tak jiej potom hlavu stěchu / mečem, [...]".

52 J. Gebauer, Legendový př́běh sv. Doroty v literature české a staročeská píseñ ku sv. Dorotě, Praha 1878 , p. 21. The author's own translation. In the old-Czech original: "Když pod meč hlavu nachýli, / zjevit' se jie v tu chvíli / dětátko velmi pěkné, / nachem oděné, / nesa v košíku ovoce, / tři jablka a tři róže / února měsiece [...]”.

53 "And she came near the pole over bed by the head of Helofernes, she took down his sword from the pole and, having moved closer to the bed, she took his hair and said »Give me strength this day, Lord, God of Israel! « And she hit him twice with all her strength in his neck and cut his head", Book of Judith, chapter 13, verses 6-8. 
sword perhaps stood behind this kind of reasoning. This explanation seems to be very likely. However, a question arises on what inspired individual authors to present this kind of weapon.

At the turn of the $14^{\text {th }}$ and $15^{\text {th }}$ century, the major contact points for the Christian and pagan world of Europe were the Balkans and Spain $^{54}$. However, there are no analogical finds of weapon from either Turkish or Spanish region available for the period under discussion. The examples which were found in the majority of cases have a straight blade. Nonetheless, in the $13^{\text {th }}$ and $14^{\text {th }}$ centuries, Europe saw slightly curved swords in the hands of the Mongolian invaders and a similar weapon was in fact known also from more distant, oriental territories. Its unconventional shape apparently inspired artists from all over Europe to use this form to enhance the narrative of their works this way. Nevertheless, it seems that this type of falchion was created in the European environment as an answer to the need of adapting the weapon - which was originally made purely for cutting - to technical progress in the construction of a warrior's defensive equipment ${ }^{55}$. However, it should not be completely ruled out that craftsmen were searching for some inspiration also in a real weapon - exotic for Europeans - of pagan nations that were moving even further into Europe. For the purpose of this article it is, however, not necessary to precisely define the origins of falchions that were exotically presented, but to draw the attention to their significance for art.

The significance of the falchion has been already outlined and it seems that this hypothesis can be also related to earlier works of art. However, it is also relevant in relation to one of the works from the discussed period, i.e. the already mentioned Epitaph of Jan of Jeřen̆. Its central motif is a couple of saints traditionally interpreted as St. Bartholomew and St. Thomas. As has been already mentioned, the weapon of one of the figures is interpreted as a falchion. Although it is obvious that the entire painting is significantly damaged ${ }^{56}$, the interpretation of the presented weapon as a knife, St. Bartholomew's attribute, is not entirely convincing. Even though in other representation from this period St. Bartholomew is depicted with a knife in his hand which has a blade similar to a falchion ${ }^{57}$, the blade is incomparably smaller and, additionally, none of the knives has either a pommel or cross-guard. These details do not coincide with the idea of a knife

${ }^{54}$ If one is to omit the last pagan stage of the Polish-Lithuanian history.

55 Slight curvature could have been originally created also while producing the weapon. When making a single-edged blade, it was a natural process of its delicate bending and if it was not constantly straightened then that constructing problem affected the final shape of the weapon.

56 The figure of the founder is evidently missing from the bottom part of the paining (A. Matěječek, Česká malba gotická. Deskové malírství 1350-1450, Praha 1938, p. 100).

57 Cf. e.g. Św. Barttomiej (St. Bartholomew) by Master Theodore at the Castle of Karlštejn, Madonna ze św. Barttomiejem i Matgorzata (Madonna with St. Bartholomew and Margaret) or Św. Jakub, Barttomiej i Filip (St. Jacob, Bartholomew and Philip) from the back side of Zmartwychwstanie (Resurrection) by the Master of the Třeboň Altarpiece. 
but they correspond with the theory which recognises the falchion as a weapon similar to a sword that can replace it for specific reasons. If the theory based on the assumption that the curved dussack (falchion) can replace a sword due to narrative reasons, it is worth trying to re-evaluate the identification of this beautiful painting, unusually important for its style. If one is to resign with associating this specific form of weapon with the word knife, it is impossible to further consider the figure to be St. Bartholomew due to the change in his attribute. His presence in the painting has not yet been justified in any other way than by accepting the object as a knife. At this point it is worth pointing out to the first point of Erwin Panofsky in his approach towards art - the pre-iconographic description, i.e. the necessity to identify the original meaning of the presented objects ${ }^{58}$. This step was, however, hastily taken probably already in 1910 and there has been no one since that time who would have reconsidered it ${ }^{59}$. Admittedly, some historians who specialise in the history of material object have later identified the weapon as a falchion but they treated it as an object and they did not analyse its symbolic meaning in their works ${ }^{60}$. In this case, however, one deals with an object which directly fits into the compositional order of the work and thus its new interpretation can most certainly enrich afterthoughts on the identification of the work itself.

If one is to assume that the falchion represents the sword's attribute, the male figure from the Epitaph of Jan of Jeřen could be interpreted as St. Paul ${ }^{61}$. In other artworks from this period this saint is regularly presented with a sword ${ }^{62}$, but similarly to other decapitated saints in later representations - he is very often beheaded with a weapon of an oriental appearance ${ }^{63}$. The avoidance of the term "sabre" is correct here, but it cannot be thoroughly ignored. It is a term slightly younger than the word falchion ${ }^{64}$, however, it seems reasonable to recognize the curved type of a falchion as one of the predecessors of a sabre which in the end completely replaced a sword, and weapons related to it, in the military equipment.

58 E. Panofsky, Význam ve výtvarném umění, Praha 1981, p. 42.

59 The fragment of the work appeared for the first time in the Auction Catalogue no. 202 in the Vienna Dorotheum (1910) no. 312. It reached Czech circles only in the 1920s (A. Matěječek, op. cit., p. 99). From the very beginning until now it has probably been erroneously interpreted, cf. e.g. Karel IV. Císař z Boži milosti..., p. 478; J. Royt, Středověké malírství v Čechách, Praha 2002, p. 104.

${ }^{60}$ E.g. E. Wágner, op. cit., p. 187.

${ }_{61}$ The work develops concepts included in the Master's thesis written under the supervision of Jan Royt: A. Kadlec, op. cit., pp. 52-53. An alternative identification of the saint is additionally mentioned in the monograph on the Master of the Třebon Altarpiece (J. Royt, Mistr ..., p. 199).

62 St. Paul from the frame of Madonna Svojšínska can serve as an example: Madonna Svojšínská, rám, zapůjčeno z kostela sv. Petra a Pavla ve Svojšíně, NG, Praha, i. č. VO 4.

63 E.g. the master IW presents St. Judith with a falchion and St. Catherine is also beheaded with this weapon in his artworks. Paul is killed with a falchion, e.g. on a painting of a Dutch master Pieter Pietersz, etc.

${ }^{64}$ E. Wagner, Z. Drobná, J. Durdík, op. cit., p. 71. Jan Durdík draws attention to the usage of the word sabre in 1468. 
One also cannot fail to notice a semantic resemblance between the name of the saint and this weapon. The name of St. Paul, who is also called "Saul", has many various forms, including: Shaul, and in Czech Šavel which can be compared to the Czech word Šavle, which means "sabre" ${ }^{65}$. However, it is possible to come across one more similarity between this type of object and the person's name. As has already been mentioned above, the widening falchion is also referred to as Malchus, i.e. the name of a servant whom St. Peter cut off an ear with the sword in the Olive Garden $^{66}$. The weapon of the soldier depicted in later periods is in fact very often similar to the sabre-like sword (falchion), and on the contrary - it is very far from traditionally understood sword ${ }^{67}$.

The reason why St. Thomas and St. Paul stand next to each other is, unfortunately, still a mystery just as it has not been closely established in the past why St. Bartholomew and St. Thomas stand next to each other ${ }^{68}$. In order to solve this mystery it is necessary to get more information on Jan of Jeřen. Since it is clear that these two saints are not portrayed together, the depiction of the two of them is probably a reflection on the life stories, experiences, and perceptions of the archdeacon mentioned above. An exception which is worth mentioning is a representation of both St. Thomas and St. Paul who simultaneously exit small windows of the astronomical clock of Prague. The figure of St. Paul nods his head in agreement, while St. Thomas shakes his head in disbelief ${ }^{69}$. Another example where both these saints are depicted together is the painting Seven Apostles from the Christian Museum in Esztergom in Hungary ${ }^{70}$. These examples prove that even

${ }_{65}$ Bible, Acts of the Apostles, chapter 13, verse 9; J. Royt, Slovnik biblické ikonografie, Praha 2007, p. 225. Most likely the author has in mind the similarity in the sound between the name Szawet (Polish version; Šavel in Czech) and a Czech sabre - šavle. In the Polish language (but not only, cf. e.g. the German Säbel, or English sabre), it is, however, definitely less significant (translator's note).

66 "Then Simon Peter, having a sword with him, drew it, hit the high priest's servant and cut off his right ear. And the servant's name was Malchos. And Jesus said this to Peter: »Put the sword away to the sheath. Am I not to drink the chalice which Father gave Me?«", Gospel of St. John, chapter 18 , verses $10-11$.

${ }^{67}$ Cf. e.g. sword of St. Peter from an alabaster plaque presenting Jesus Christ on the Mount of Olives from the Church of St. Florian in Krásné Březno, although there are many more representations like this one.

68 The only indication is the fact that while mentioning the Apostles in some of the instances these saints, Thomas and Bartholomew, are placed next to each other. In other instances, Philip the Apostle is placed after St. Bartholomew. Another argument could be additionally made by the Apostles' mission in India where they were both killed (J. Royt, Slovnik..., p. 48, 281-282; see, e.g. J. de Voragine, op. cit.).

69 It should be mentioned that this work is much older. Sadly, not much is known about the real appearance of the clock from the period of its construction (beginning of the $15^{\text {th }}$ century). Briefly on this topic: E. Poche, Prahou krok za krokem, Praha-Litomyšl 2001, p. 156.

${ }_{70}$ Master BE from Csegöld, Seven Apostles, 1494, Christian Museum, Esztergom, inv. nos. 55 and 65 . 
though the couple - Thomas and Paul - is not common in art, their depiction together should by no means be treated as a completely isolated case.

There is little information available on Jan of Jeřen. The majority of them records his church career which he apparently started due to reasons quite common at that time. The first born son and heir of the secular estates and distinctions was his brother Heřman of Nečtin, sometimes referred to as Heřman of Jeřeň or Hrádek. Jan received the best education for which he travelled to north Italian cities of Padua and Bologna ${ }^{71}$. Even before the end of his travelling period, the well-read young man had become a parish priest in the Church of St. Barbara in Maštov where he remained until 1379. However, his university years did not finish together with his return from the north of Italy. Right after his return in 1378, he began to be active at the University of Padua where he stayed until his death. In 1381, he graduated with a Bachelor's degree in canon law ${ }^{72}$. In 1380, he was appointed a parish priest in the Church of the Saint Peter and Paul where he undoubtedly did not work for long and the possessions he had gained were given away for rent ${ }^{73}$. Prebends in the town of Kbely were a secure source of income ${ }^{74}$. Jan's relationship with his elder brother Heřman were without a doubt very good and they probably helped him in the development of his church career ${ }^{75}$. The titles of a canon of Prague chapter and an archdeacon of Hrádek were the highlight moment of his career ${ }^{76}$. The mutual enterprises of the brothers of Jeřeň ended together with Jan's death in 1395, recalled by the epitaph which is the main topic of this article. The elder brother, Heřman, survived Jan of Jeřeň for many years and he made himself known as a progenitor of a large family that prospered also in the following years, taking the side of Sigismund, brother of Wencelaus IV, during the Hussite Wars ${ }^{77}$. Unfortunately, information available on Jan is scanty and it cannot help to interpret reasons for the presence of two specific saints on the central painting of the Epitaph from St. Vitus Cathedral in Hradčany.

71 J. Tř́ska, Životopisný slovník predhusitské pražské univerzity 1348-1409, Praha 1981, p. 260. It is in the Bologna museum where one can find a very interesting ivory plaque presenting saints and angels. There are also St. Paul and Bartholomew amongst the saints. St. Paul is equipped with a falchion, while St. Bartholomew holds a small knife with a short blade on otherwise blunt side of the blade. Museo Civico Medievale, Bologna, inv. no. 702 (first half of the $15^{\text {th }}$ century). It should be noted that we are dealing here with a slightly younger object.

72 Ibidem.

73 O. Schmidt, Topografie kostelní sitě na území plzeňského děkanátu do doby husitské, Brno 2012 (bakalářská práce, Masarykova univerzita, Filosofická fakulta), p. 42.

74 V.V. Tomek, Déjepis města Prahy. Díl V., Praha 1905, p. 126.

75 Already the first Jan's parish church in Mašt'ov belonged to the Nečtin family's sphere of interest and the joint activity is referred to in, for example, the two brothers' request in the dispute over the nomination to the Church of St. Vojtěch in Vejprnice, or the Church of the Holy Trinity in Jezna. See O. Schmidt, op. cit., p. 35, 61.

${ }^{76}$ J. Tř́ska, op. cit., p. 260.

77 Ottův slovník naučný III, Praha 1890, pp. 744-745. 


\section{CONCLUSIONS}

Although the unusually-looking weapon, which can be overall referred to as dussack, or eventually as a malchus or falchion ${ }^{78}$, is shrouded in more than one secret, it is possible to perceive it as a particular element of art at the turn of the $14^{\text {th }}$ and $15^{\text {th }}$ centuries. Through its unusual form, the falchion deepens the narrative ability of the artwork in which it appears, as, e.g. in the case of presenting it as an attribute where a weapon is, first and foremost, associated with a saint's beheading (in Judith's case not with the decapitation of the saint, but with killing Holofernes). In these cases, the curved falchions undoubtedly indicate pagan origins of the owner of a weapon with the help of which this or that character was beheaded. In the situation in which falchions do not influence so greatly the compositional order of the artwork, they symbolically move the place of action to culturally and chronologically distant territories. It seems that specifically at the turn of the $14^{\text {th }}$ and $15^{\text {th }}$ century, the curved falchion can be always considered a figurative object with a function similar to, e.g. helmet cover ${ }^{79}$. Taking into consideration a limited number of archaeological evidence of this weapon, it is possible to regard the discussed figurative object as a material object, although - particularly in the Czech and broader European environment - not overly common at least at that time.

On the basis of these considerations, it is moreover possible to offer an alternative interpretation of the iconography of the Epitaph of Jan of Jeřen and broaden the discourse on the artworks of the "Beautiful Style" in Bohemia. Although the figures on one of the fragments from the Epitaph are traditionally considered as St. Bartholomew and St. Thomas, the figure with a falchion may be as well regarded as St. Paul. There are arguments which are impossible to ignore in favour of both views. However, it is known that the artistic work of the past had left us with many similar riddles and thus one can embark on other exciting journeys to the world of our ancestors' art and thought.

\section{REFERENCES}

Beneš C., Gamber O., Ochrané zbraně: České vydání, Graz 1972.

Boeheim W., Handbuch der Waffenkunde, Leipzig 1890.

Chronicon Pictum, Marci de Kalt, Chronica de gestis Hungarorum ab origine gentis ad a. 1330, Országos Széchényi Könyvtá, Budapest 2003.

Demmin A., Encyklopädie der Waffenkunde, Leipzig 1893.

Dubec I., Válečné a turnajské erbovni oděni v 1. polovině 14. století, [in:] Sborník semináre historie odivání, Zlín 2009.

Durdík J., Husitské vojenství, Praha 1953.

Francastel P., Figura a misto - vizuální rád v italském maliřstvív 15. století, Praha 1984.

Gebauer J., Legendový přiběh sv. Doroty v literatuře české a staročeská piseň ku sv. Dorotě, Praha 1878.

78 P. Klučina, op. cit., p. 406, 407.

79 F. Šmahel, Diví Lidé (v imaginaci) pozdního středověku, Praha 2012, pp. 123-124. 
Kadlec A., Zbraně a zbroj v deskové malbě doby vlády Václava IV., Ústí nad Labem 2013 (diplomová práce, Univerzita Jana Evangelisty Purkyně, Filosofická fakulta).

Karel IV. Císař z Boži milosti. Kultura a umění za vlády Lucemburků 1310-1437, ed. J. Fajt, Praha 2006.

Klučina P., Zbroj a zbraně. Evropa 6.-17. století, Praha-Litomyšl 2004.

Klučina P., Romaňák A., Člověk, zbraň a zbroj v obraze doby 5.-17. stol., Praha 1983.

Krrížek L., Čech J.K.Z., Encyklopedie zbrani a zbroje, Praha 1997.

Matěječek A., Česká malba gotická. Deskové malírství 1350-1450, Praha 1938.

Ottův slovník naučný III, Praha 1890.

Panofsky E., Význam ve výtvarném uméní, Praha 1981.

Petráň J., Dějiny hmotné kultury I, Praha 1985.

Ptáčková T., Pưvod názvio středověkých zbrani použivaných v Čechách a na Moravě (zbraně chladné - sečné a bodné) (bakalářská práce), Brno 2010.

Royt J., Mistr Třeboňského oltáre, Praha 2013.

Royt J., Slovník biblické ikonografie, Praha 2007.

Royt J., Středověké malírství v Čechách, Praha 2002.

Schmidt O., Topografie kostelni sitě na územi plzeňského děkanátu do doby husitské, Brno 2012 (bakalářská práce, Masarykova univerzita, Filosofická fakulta).

Šach J., Chladné zbraně, Praha 2004.

Šmahel F., Diví Lidé (v imaginaci) pozdního středověku, Praha 2012.

Tomek V.V., Dějepis města Prahy. Díl V., Praha 1905.

Tříska J., Životopisný slovnik předhusitské pražské univerzity 1348-1409, Praha 1981.

Vilikovský J., Legenda o svaté Kateřině, Praha 1946.

Viollet-le-Duc E.E., Dictionnaire raisonné du mobilier francais V, Paris 1874.

Voda P. a kol., Předběžná zpráva o oděvni analýze nástěnných maleb v kostele ve Slavětíně nad Ohři, [in:] Sbornik semináre historie odivání. Díl druhý, Zlín 2009.

Voragine J. de, Zlatá legenda, Praha 2012.

Wagner E., Drobná Z., Durdík J., Kroje, zbroj a zbraně doby předhusitské a husitské, Praha 1956.

Wágner E., Sečné a bodné zbraně, České Budějovice 1993.

Zíbrt Č., Dějiny kroje v zemích českých od dob nejstaršich až po války husitské, Praha 1892.

Žákovský P., Tesák z holešické tvrze na př́bramsku, [in:] Non sensistis gladios. Studia ofiarowane Marianowi Głoskowi w 70. rocznice urodzin, red. O. Ławrynowicz, J. Maik, P.A. Nowakowski, Łódź 2011.

Žákovský P., Tesáky a problematika jednosečných zbrani středověku a raného novověku, Brno 2014 (disertační práce, Masarykova univerzita, Filosofická fakulta).

Žákovský P., Tesáky s prořezávanými záśtitnými trny z moravských sbirek, „Archeologické rozhledy" 2011, roč. 62, č. 3.

Žákovský P., Tesáky ze sbírek Státního hradu Zvíkova, „Castellologica Bohemika“ 2008, roč. 11, č. 1.

\section{STRESZCZENIE}

Artykuł dotyczy współczesnej dyskusji na temat Epitafium Jana z Jeřeně i dowodzi, że dwaj święci mężczyźni, których wymienia przekaz, a których tradycyjnie identyfikuje się z Bartłomiejem i Tomaszem, nie muszą być tak identyfikowani. Ponadto autor opisał podstawową potrzebę radzenia sobie ze zwizualizowanymi obiektami. Ich interpretacje mogą zasadniczo wpływać na potencjał narracyjny dzieła. Wskazano także na konieczność multidyscyplinarnego podejścia do tego rodzaju przekazów. Zostało to wykazane na przykładzie pewnego typu miecza (falchion) w kontekście sztuki średniowiecznej Europy Środkowej.

Słowa kluczowe: historia; kultura; sztuka; Wacław IV; miecz; Epitafium Jana z Jeřené; średniowiecze 
APPENDIX

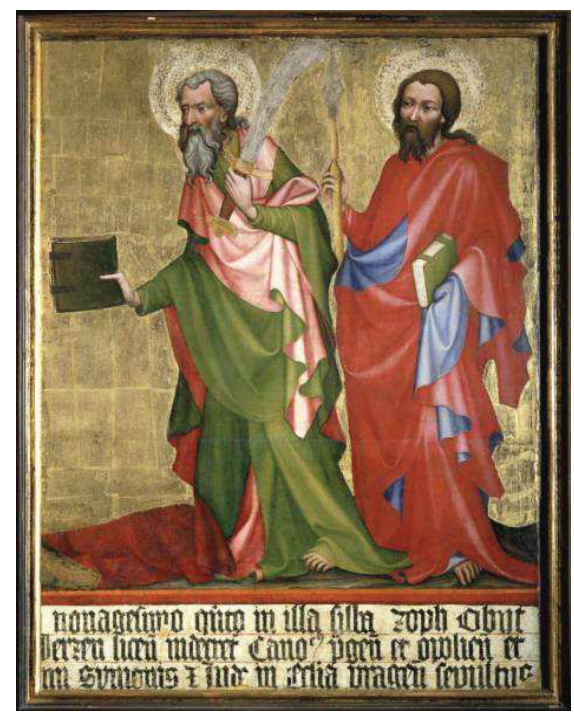

Fig. 1. Epitaph of John of Jeřeně (NG, Prague, ID O 1268), 1395

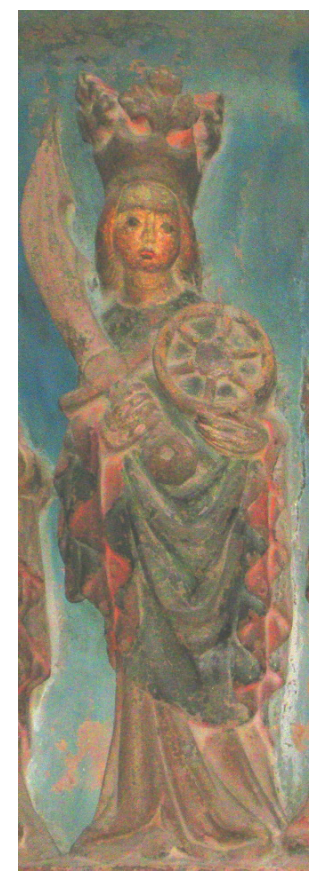

Fig. 3. St. Catherine from the church of St. Lawrence in Nuremberg (around 1410)



Fig. 2. Transformation of the falchion (A. Kadlec, 2019)

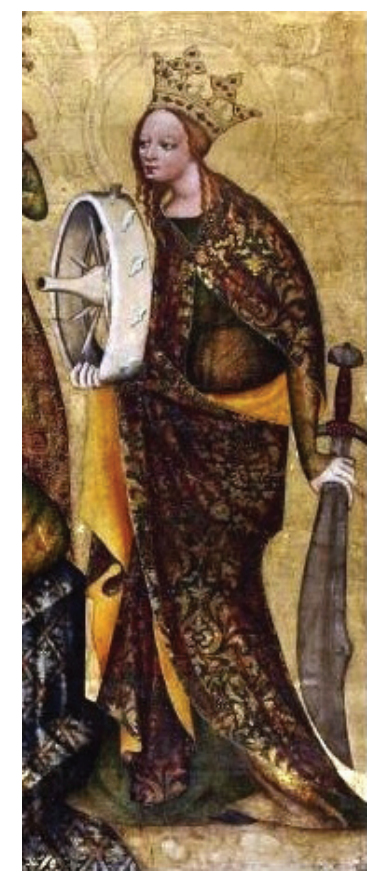

Fig. 4. St. Catherine of Graudenz Altar (around 1400) 